\title{
PENGARUH PENAMBAHAN EKSTRAK BUAH MENGKUDU (MORINDA CITRIFOLIA LINN) DALAM PENGENCER TERHADAP MOTILITAS SPERMATOZOA PADA SEMEN CAIR SAPI BALI
}

\author{
Sahiruddin Sabile1), Abd. Latief Toleng'), Muhammad Yusuf ${ }^{1)}$, \\ Sri Firmiaty ${ }^{2)}$, Muhammad Idrus ${ }^{2)}$, Zulkharnaim ${ }^{1)}$, Nasriyanto ${ }^{2)}$ \\ 1.Fakultas Peternakan Universitas Hasanuddin, \\ 2. Fakultas Pertanian Universitas Bososwa \\ Email : sabilesahir@gmail.com
}

\begin{abstract}
ABSTRAK
The processing of liquid cement is likely to decrease sperm motility. It can be caused by the oxidative reaction to increase the amount of free radicals. Noni (Morinda citrifolia Linn) contains many antioxidants that can serve counteract free radicals. This study aims to determine the addition of extracts of noni (Morinda citrifolia Linn) in order to maintain the individual motility of spermatozoa in the semen liquid Bali cattle. This research was conducted at the Laboratory of Animal Reproduction Semen Processing Unit Faculty of Animal Husbandry Hasanuddin University Makassar. Extracts of noni fruit (Morinda citrifolia Linn) effect on sperm motility $(P<0.05)$. Storage $P 0$ at $3 h$ to day 2 showed higher motility. Concentration $0,02 \mathrm{gr} / \mathrm{ml}(P 1)$ gives the best results in maintaining sperm motility on day $3 r d$ to 5 th. Extracts of noni fruit (Morinda citrifolia Linn) can retain sperm motility because many contain many antioxidants that serve to neutralize free radicals cause a decrease in sperm motility during equilibration at $5{ }^{\circ} \mathrm{C}$.
\end{abstract}

Keywords: Cement Liquid, Noni Extract, Sapi Bali

Proses pengolahan semen cair kemungkinan dapat terjadi penurunan motilitas spermatozoa. Hal ini dapat disebabkan oleh terjadinya reaksi oksidatif yang dapat meningkatkan jumlah radikal bebas. Buah mengkudu (Morinda citrifolia Linn) mengandung banyak antioksidan yang dapat berfungsi menangkal radikal bebas. Penelitian ini bertujuan untuk mengetahui penambahan ekstrak buah mengkudu (Morinda citrifolia Linn) dalam upaya mempertahankan motilitas individu spermatozoa pada semen cair sapi Bali. Penelitian ini dilaksanakan di Laboratorium Reproduksi Ternak Unit Prosesing Semen Fakultas Peternakan Universitas Hasanuddin Makassar. Ekstrak buah mengkudu (Morinda citrifolia Linn) berpengaruh terhadap motilitas spermatozoa $(P<0,05)$. Penyimpanan P0 pada 3 jam sampai hari ke 2 menunjukkan motilitas spermatozoa tinggi. Konsentrasi $0.02 \mathrm{gr} / \mathrm{ml}$ pengencer (P1) memberikan hasil terbaik dalam mempertahankan motilitas spermatozoa pada hari ke-3 sampai ke-5. Ekstrak buah mengkudu (Morinda citrifolia Linn) dapat mempertahankan motilitas spermatozoa dikarenakan banyak mengandung banyak antioksidan yang berfungsi menetralisir radikal bebas penyebab penurunan motilitas spermatozoa selama proses ekuilibrasi pada suhu $5{ }^{\circ} \mathrm{C}$.

Kata Kunci : Semen Cair, Ekstrak Mengkudu, Sapi Bali. 


\section{PENDAHULUAN}

Program pemerintah dalam upaya meningkatkan mutu genetik ternak dan jumlah populasi sapi potong antara lain yaitu melalui pelaksanaan program Inseminasi Buatan (IB). Tingkat keberhasilan IB dipengaruhi oleh empat faktor utama yaitu kualitas semen, ternak betina sebagai akseptor, ketrampilan tenaga inseminator, dan pengetahuan peternak. Keempat faktor ini sangat berkaitan antara satu dengan yang lain dan apabila salah satu nilainya rendah maka hasil IB juga rendah (Tambing, 2001). Salah satu faktor yang mempengaruhi keberhasilan IB adalah kualitas semen.

Sapi Bali (Bos Indicus) merupakan salah satu sapi potong asli Indonesia hasil domestikasi dari banteng (Bos-Bibos Banteng) dan memiliki potensi besar untuk mensuplai kebutuhan protein masyarakat Indonesia. Keunggulan sapi Bali terletak pada daya adaptasinya terhadap lingkungan yang baru, suhu udara, kelembaban dan angin, maupun kondisi lahan, pakan dan penyakit. Kelebihan sapi Bali yang lain yaitu pertumbuhanya cepat, persentase beranak mencapai 80\% (Hardjosubroto, 1994). Fertilitas sapi Bali rata- rata $83 \%$ artinya setiap perkawinan memberikan peluang kebuntingan 83\%. Produksi karkas Sapi Bali cukup meningkat yaitu 56\% sehingga dapat dijadikan sumber daging sapi potong (Guntoro, 2002). Seiring pendapat Gunawan dkk. (1998), bahwa sapi Bali memiliki persentase calf crop 81-91\% dan persentase karkas sampai 96,6\%, serta mempunyai daya tahan terhadap pakan yang terbatas, iklim maupun caplak. Dinyatakan Guntoro (2002) bahwa kemampuan sapi Bali menghasilkan anak dalam setahun berkisar 80 - 86\%. Perbaikan manajemen pemeliharaan dan pakan terbukti dapat meningkatkan kualitas daging sapi Bali sampai mendekati kualitas daging sapi impor. Salah satu upaya mempercepat menigkatkan mutu genetik ternak maka pemerintah mencanangkan program IB. Salah satu faktor yang mempengaruhi keberhasilan IB yaitu kualitas semen yang digunakan.

Semen yang berkualitas dapat diperoleh dari pejantan unggul yang sehat, tumbuh dan berkembang secara optimal sehingga mencapai dewasa kelamin pada umur dan bobot badan tertentu sesuai potensi genetiknya. Usaha yang dilakukan untuk menjaga kualitas semen tetap baik dan dapat dimanfaatkan sewaktu-waktu adalah dengan pengenceran dan pengawetan pada suhu tertentu dengan menambahkan bahan yang dibutuhkan spermatozoa saat disimpan. Semen yang diejakulatkan oleh pejantan ditampung menggunakan vagina buatan, selanjutnya diberi pengencer.

Pengencer semen adalah larutan isotonis (memiliki tekanan osmotik yang sama dengan plasma darah) yang mengandung bahan-bahan yang bersifat buffer (memelihara larutan dari perubahan $\mathrm{pH}$ ), bahan nutrisi bagi kelangsungan hidup sperma, dan mampu memelihara sperma dari cekaman dingin (cold shock) (Feradis, 2010).

Teknik IB yang sudah umum dipakai dengan menggunakan semen beku (frozen semen) maupun semen cair (chilled semen). Permasalahan dalam penanganan semen beku yang sering dijumpai di lapang adalah kesulitan dan keterlambatan dalam memperoleh nitrogen cair serta keterbatasan container di lapangan (Hedah dan Herliantien, 1993). Kendala pada penggunaan semen beku di daerah maka dapat digunakan semen cair sebagai alternatif pengganti semen beku untuk keperluan IB.

Proses pembuatan semen cair maupun semen beku terjadi penurunan kualitas sperma akibat stress oksidatif yang dapat meningkatkan jumlah radikal bebas. Dinyatakan oleh Agarwal et al. (2005) radikal bebas dapat membahayakan motilitas sperma atau kemampuan sperma untuk bergerak. Akibatnya, sperma yang bergerak 
lambat kemungkinan juga tidak mampu membuahi sel telur. Adanya efek tersebut terkait dengan radikal bebas, untuk itu diperlukan antioksidan yang bertindak sebagai "pemangsa" radikal bebas untuk melindungi spermatozoa. Jumlah antioksidan terbanyak pada makanan bersumber dari buah dan sayur, salah satunya adalah mengkudu (Morinda citrifolia Linn) (Oguntibeju et al., 2010).

Buah mengkudu (Morinda citrifolia Linn) mengandung banyak antioksidan yaitu karoten, vitamin $\mathrm{C}$, xeronin, dan proxeronin yang dapat berfungsi menangkal radikal bebas (Andarwulan, 1992). Vitamin C mempunyai kemampuan menguatkan kestabilan jaringan pelindung membran plasma terhadap peroksida lipid, sehingga dapat mempertahankan kualitas dan fertilitas semen. Berdasarkan hal tersebut di atas, maka penelitian ini dilakukan untuk mengetahui pengaruh penambahan ekstrak mengkudu (Morinda citrifolia Linn) dalam upaya meningkatkan kualitas semen cair sapi Bali.

\section{TUJUAN DAN KEGUNAAN}

Penelitian ini bertujuan untuk mengetahui penambahan ekstrak mengkudu (Morinda citrifolia Linn) dalam upaya meningkatkan kualitas semen cair sapi Bali pada suhu $5^{0} \mathrm{C}$.

Kegunaan penelitian ini diharapkan dapat menghasilkan suatu pengetahuan baru dalam pemanfaatan ekstrak mengkudu (Morinda citrifolia Linn) sebagai bahan suplement pada pengencer semen segar sapi Bali yang disimpan pada suhu $5^{\circ} \mathrm{C}$.

\section{MATERI DAN METODE}

Penelitian ini dilaksanakan di Laboratorium Reproduksi Ternak Unit Prosesing Semen Fakultas Peternakan Universitas Hasanuddin Makassar. Materi penelitian menggunakan semen sapi bali umur lima tahun sebanyak satu ekor yang sebelumnya diseleksi dari lima ekor pejantan. Parameter yang diukur dalam penelitian ini yakni, motilitas massa dan individu spermatozoa sebelum dan setelah equilibrasi. Sampel semen segar yang digunakan dalam penelitian ini, yaitu dengan motilitas individu $\geq 70 \%$ dan motilitas massa minimal (++) dengan konsentrasi $500 \times 10^{6}$ per ml. semen tersebut dibagi dalam lima perlakuan dengan ulangan masing-masing lima kali.

P0 : Pengencer tanpa ekstrak buah mengkudu (kontrol).

P1 : Suplementasi ekstrak mengkudu $0,02 \mathrm{gr} / \mathrm{ml}$ pengencer

P2 : Suplementasi ekstrak mengkudu $0,04 \mathrm{gr} / \mathrm{ml}$ pengencer

P3 : Suplementasi ekstrak mengkudu $0,06 \mathrm{gr} / \mathrm{ml}$ pengencer

P4 : Suplementasi ekstrak mengkudu 0,08 gr $/ \mathrm{ml}$ pengencer

\section{Prosedur Penelitian}

\section{Penampungan Semen}

Proses penampungan semen dilakukan pada pagi hari antara jam $08.00-10.00$ selama dua kali seminggu dengan menggunakan vagina buatan.

\section{Proses Pembuatan Pengencer}


Mencampurkan larutan Andromed dan Aquadest ke dalam wadah dengan perbandingan 1 : 4 secara perlahan lalu diaduk dengan menggunakan pengaduk kemudian disimpan pada water bath dengan suhu $37^{0} \mathrm{C}$.

3. Proses Pembuatan Ekstrak Mengkudu (Morinda citrifolia Linn)

- Buah mengkudu dibersihkan dan dipotong tipis-tipis, kemudian dikeringkan dengan cara diangin-anginkan ditempat yang terlindung dari cahaya matahari.

- Dimasukkan kedalam oven pada suhu $40^{\circ} \mathrm{C}$ (3 hari)

- Digiling hingga membentuk serbuk (simplisia).

- Simplisia direndam ke dalam pelarut etanol 96\% sampai terendam seluruhnya selama 3 x 24 jam.

- Diaduk 2 kali sehari selama 3 hari kemudian disaring dengan kertas penyaring.

- Residu dimaserasi kembali dengan cara yang sama, sampai tiga kali hingga bahan-bahan larut.

- Cairan yang dihasilkan diuapkan sampai diperoleh ekstrak yang kental.

\section{Analisis Data}

Data hasil pengamatan dianalisis menggunakan Rancangan Acak Lengkap (RAL) yang terdiri dari 5 perlakuan dan 5 ulangan dibantu program SPSS 21 (Santoso, 2013).

Analisis pola rancangan yang digunakan adalah $\mathrm{Y}=\mu+\mathrm{A} i+\mathrm{Eij}$

Keterangan :

$\mathrm{Y} \quad=$ hasil pengamatan.

$\mu \quad=$ rata-rata keseluruhan.

$\mathrm{Ai} \quad=$ pengaruh penambahan ekstrak mengkudu terhadap kualitas semen cair, $(\mathrm{i}=1,2$, dan 3$)$.

Eij $=$ pengaruh kesalahan perlakuan.

\section{HASIL DAN BAHASAN}

Data hasil pengamatan motilitas individu yang diberikan suplementasi ekstrak buah mengkudu ke dalam pengencer disajikan pada Tabel 1.

Tabel 1. Rataan Motilitas Individu Semen Sapi Bali

\begin{tabular}{cccccccc}
\hline \multirow{2}{*}{ PERLAKUAN } & \multicolumn{7}{c}{ MOTILITAS INDIVIDU (\%) } \\
\cline { 2 - 7 } & Awal & 3 jam & 1 hari & 2 hari & 3 hari & 4 hari & 5 hari \\
\hline P0 & 83,22 & 78,46 & 68,61 & 60,79 & 51,83 & 41,14 & 18,80 \\
P1 & 83,22 & 75,98 & 65,32 & 60,55 & 53,71 & 45,12 & 26,57 \\
P2 & 83,22 & 70,94 & 61,21 & 55,63 & 51,01 & 40,90 & 24,87 \\
P3 & 83,22 & 65,93 & 58,63 & 53,25 & 49,15 & 39,28 & 18,13 \\
P4 & 83,22 & 65,54 & 49,38 & 44,83 & 40,56 & 32,02 & 17,87
\end{tabular}


Hasil analisis sidik ragam menunjukkan bahwa suplementasi ekstrak buah mengkudu (Morinda citrifolia Linn) berpengaruh terhadap motilitas spermatozoa $(\mathrm{P}<0,05)$. Penyimpanan $\mathrm{P} 0$ pada 3 jam sampai hari ke 2 menunjukkan motilitas spermatozoa tertinggi namun tidak menunjukkan adanya perbedaan nyata terhadap P1 $(\mathrm{P}>0,05)$. Suplementasi ekstrak mengkudu menunjukkan adanya penurunan motilitas spermatozoa, seiring meningkatnya kadar ekstrak buah mengkudu. Dinyatakan oleh Rahardhianto dkk. (2012) bahwa pemberian larutan dengan konsentrasi yang lebih besar tidak sesuai sebagai media hidup karena sel spermatozoa dapat tetap melakukan metabolisme secara maksimal bila pengencer bersifat isotonik. Membran sel bersifat semipermeable sehingga baik pengencer yang bersifat hipotonik ataupun hipertonik akan mempengaruhi transfer air melalui membran dan menyebabkan rusaknya integritas sel (Souhoka, 2009). Dinyatakan Sonjaya (2005) bahwa apabila larutan ditempatkan dalam cairan yang mempunyai tekanan osmotik sama maka sel tersebut tidak akan membengkak atau berkerut, dan sebaliknya.

Diduga pula level ekstrak buah mengkudu (Morinda citrifolia Linn) yang diberikan cukup tinggi sehingga dimungkinkan adanya perubahan $\mathrm{pH}$ dikarenakan vitamin $\mathrm{C}$ yang terkandung didalamnya bersifat asam dan juga kandungan antioksidan dalam jumlah banyak dapat bersifat prooksidan sehingga akan mengakibatkan penurunan motilitas. Dinyatakan Sumarsono (1998) spermatozoa sangat peka terhadap perubahan $\mathrm{pH}$ medium dari keadaan netral, terutama terhadap $\mathrm{pH}$ rendah. Ditambahkan Mc. Nulty et al. (2006) antioksidan juga dapat menjadi prooksidan yang menyebabkan oksidasi dalam tubuh, seperti vitamin $C, D, E, \beta$ karoten, teh hijau, ubiquinone, curcumin dan zinc.

Hasil pengamatan pada hari ke-3 sampai ke-5 menunjukkan bahwa dengan suplementasi ekstrak buah mengkudu (Morinda citrifolia Linn) dengan konsentrasi 0,02 gr (P1) memberikan hasil yang lebih baik dalam mempertahankan motilitas spermatozoa, dengan rataan motilitas 53,71, 45,12 dan 26,57 dan menunjukkan adanya perbedaan nyata $(\mathrm{P}>0,05)$ antara $\mathrm{P} 0$ dan $\mathrm{P} 1$ pada hari ke-5. Hal ini dapat terjadi dikarenakan ekstrak buah mengkudu (Morinda citrifolia Linn) mengandung banyak antioksidan yang berfungsi menangkal radikal bebas yang merupakan penyebab penurunan motilitas spermatozoa selama ekuilibrasi. Hal ini Sesuai pendapat Wibisono (2001) bahwa Pemberian vitamin C sampai dosis $0.20 \mathrm{mg} / \mathrm{gram}$ berat badan/hari dapat mengurangi jumlah spermatozoa yang mengalami kerusakan akibat radikal bebas karena vitamin $\mathrm{C}$ mampu menetralisir radikal bebas.Motilitas sperma pada hari ke-4 pada P0, P1 dan P2 menunjukkan nilai $>40 \%$ sehingga masih memenuhi syarat untuk dilakukan inseminasi buatan (IB). Sesuai pendapat Susilawati (2010) bahwa nilai PTM minimal 40\% sebelum dilakukan inseminasi buatan.

\section{SIMPULAN}

Berdasarkan hasil pengamatan disimpulkan bahwa suplementasi ekstrak buah mengkudu (Morinda citrifolia Linn) sebanyak $0.02 \mathrm{gr} / \mathrm{ml}$ pengencer dapat mempertahankan motilitas individu spermatozoa sampai hari ke-5 ekuilibrasi dengan suhu $5^{\circ} \mathrm{C}$ pada semen cair sapi Bali. 


\section{DAFTAR PUSTAKA}

Agarwal A, S. Prabakaran, T. Said. 2005. Prevention of Oxidative Stress Injury to sperm.J Adrol.26:654-660.

Andarwulan, N. 1992. Kimia vitamin. Jakarta: CV. Rajawali.

Feradis, 2010. Bioteknologi Reproduksi Pada Ternak. Penerbit Alfabeta, Bandung.

Gunawan, Pamungkas dan L. Affandhy,1998. Potensi Sapi Bali, Produktifias dan nilai ekonomis. Penerbit Kanisius. Yogyakarta.

Guntoro, 2002. Membudidayakan Sapi Bali. Penerbit Kanisius, Jakarta.

Hardjosubroto W. 1994. Aplikasi Pemuliabiakan Ternak di Lapangan. PT.Gramedia Widiasarana Indonesia, Jakarta.

Hedah, D. dan Herliantien. 1993. Handling Semen Beku. Pros. Pertemuan Pembahasan Hasil Penelitian Seleksi Bibit Sapi Madura Guna Meningkatkan Mutu Sapi Madura. Sub Balitnak, Grati, 8 September 1993.

Mc. Nulty, H.P., J. Byun, S.F. Lockwood, R.F. Jacob, R.P. Mason. 2006.Differential Effect of Carotenoid on Lipid Peroxidation due to Membran Interactions: $X$-Ray Diffraction Analysis. Biochemica et biophysica Acta. Vol 1768: 167174.

Oguntibeju OO, AJ. Esterhuyse, EJ. Truter. 2010. Possible Role of Red Palm Oil Supplementation in Reducing Oxidative Stress in HIV/AIDS and TB Patients: A Review. Journal of Medical Plant Research.4(3): 188-196.

Rahardhianto A, N. Abdulgani, dan N. Trisyani. 2012. Pengaruh Konsentrasi Larutan Madu dalam $\mathrm{NaCl}$ Fisiologis terhadap Viabilitas dan Motilitas Spermatozoa Ikan Patin (pangasius pangasius) selama Masa Penyimpanan. JURNAL SAINS DAN SENI ITS Vol. 1, No. 1, (Sept. 2012) ISSN: 2301928X.

Sonjaya, H. 2005. Bahan Ajar Fisiologi Ternak Dasar. Fakultas PeternakanUniversitas Hasanuddin:Makassar.

Souhoka, DF., M.J. Mataluta, W.M.M. Nalley dan M. Rizal. 2009. "Laktosa Mempertahankan Daya Hidup Spermatozoa Kambing Peranakan Etawah yang Dipreservasi dengan Plasma Semen Domba Priangan, 'Jurnal Veteriner September, Vol. 10, No 3 (2009) 135-142.

Sumarsono, T. 1998. Peningkatan Kualitas Spermatozoa Kerbau Lumpur dengan Penambahan Asam Askorbat dalam Pengencer Semen Beku. Tesis. Program Pascasarjana, Institut Pertanian Bogor, Bogor.

Susilawati T. 2010. Spermatologi. UB Press. Brawijaya University. Malang. Tambing, S.N. 2001. Penerapan Bioteknologi Inseminasi Buatan dalam Pembinaan Sains Program Pasca Serjana S3 IPB, Bogor.

Wibisono M. 2001. Pemanfaatan Vitamin C untuk Meningkatkan Jumlah Spermatozoa pada Mus musculus yang Dipapar Gelombang Ultrasonik. Jurnal Media Medika, Fakultas Kedokteran Universitas Brawijaya No.3 (20) Juli-September 2002 